\title{
Pigmentiphaga daeguensis sp. nov., isolated from wastewater of a dye works, and emended description of the genus Pigmentiphaga
}

Correspondence
Jung-Hoon Yoon
jhyoon@kribb.re.kr

\author{
Jung-Hoon Yoon, ${ }^{1}$ So-Jung Kang, ${ }^{1}$ Wonyong $\mathrm{Kim}^{2}$ and Tae-Kwang $\mathrm{Oh}^{1}$ \\ ${ }^{1}$ Korea Research Institute of Bioscience and Biotechnology (KRIBB), PO Box 115, Yusong, \\ Taejon, Korea \\ ${ }^{2}$ Department of Microbiology, College of Medicine, Chungang University, 221 Heukseok-dong, \\ Seoul, Korea
}

The genus Pigmentiphaga was proposed by Blümel et al. (2001) with Pigmentiphaga kullae as the sole recognized species of the genus. Phylogenetic analysis based on $16 \mathrm{~S}$ rRNA gene sequences showed that the genus Pigmentiphaga falls within the Betaproteobacteria (Blümel et al., 2001). In this study, we report on the taxonomic characterization of a Pigmentiphaga-like bacterial strain, $\mathrm{K} 110^{\mathrm{T}}$, which was isolated from wastewater collected from a dye works.

Wastewater collected from a dye works at Daegu, Korea, was used as the source for the isolation of bacterial strains. Strain $\mathrm{K} 110^{\mathrm{T}}$ was isolated by means of the standard dilution plating technique on trypticase soy agar (TSA; Difco) at $30^{\circ} \mathrm{C}$. P. kullae DSM $13608^{\mathrm{T}}$ was obtained from the Deutsche Sammlung von Mikroorganismen und Zellkulturen (Braunschweig, Germany). The morphological, physiological and biochemical characteristics of strain $\mathrm{K} 110^{\mathrm{T}}$ were

Abbreviation: rep-PCR, repetitive extragenic palindromic PCR.

The GenBank/EMBL/DDBJ accession number for the 16S rRNA gene sequence of strain $\mathrm{K} 110^{\top}$ is $\mathrm{EF} 100696$.

rep-PCR fingerprints and cellular fatty acid compositions for strain $\mathrm{K} 110^{\top}$ and $P$. kullae DSM $13608^{\top}$ are available as supplementary material with the online version of this paper. investigated using routine cultivation on TSA at $37^{\circ} \mathrm{C}$. Cell morphology was examined by using light microscopy (E600; Nikon) and transmission electron microscopy with cells from exponentially growing cultures. Flagellation was determined by using a Philips CM-20 transmission electron microscope with cells from exponentially growing cultures: for this purpose, cells were negatively stained with $1 \%(\mathrm{w} / \mathrm{v})$ phosphotungstic acid and the grids were examined after being air-dried. The Gram reaction was determined using the bioMérieux Gram stain kit according to the manufacturer's instructions. Growth at various temperatures (4$50{ }^{\circ} \mathrm{C}$ ) was measured on TSA. The $\mathrm{pH}$ range for growth was determined in nutrient broth (Difco) adjusted, prior to sterilization, to various $\mathrm{pH}$ values $(\mathrm{pH} 4.5-10.5$, in increments of $0.5 \mathrm{pH}$ units) by the addition of $\mathrm{HCl}$ or $\mathrm{Na}_{2} \mathrm{CO}_{3}$. Growth in the absence of $\mathrm{NaCl}$ and at various $\mathrm{NaCl}$ concentrations $(0.5 \%, \mathrm{w} / \mathrm{v}$, and $1.0-10.0 \%, \mathrm{w} / \mathrm{v}$, at increments of $1.0 \%)$ was investigated using trypticase soy broth prepared according to the formula of the Difco medium except that no $\mathrm{NaCl}$ was used. Growth under anaerobic conditions was determined after incubation in an anaerobic chamber on TSA and on TSA supplemented with nitrate, both of which had been prepared anaerobically under a nitrogen atmosphere. Catalase and oxidase activities and hydrolysis 
of casein, gelatin, hypoxanthine, starch, Tweens $20,40,60$ and 80 , tyrosine, urea and xanthine were determined as described by Cowan \& Steel (1965). DNase activity was examined by using DNase test agar with methyl green (Difco). Hydrolysis of aesculin and nitrate reduction were studied as described previously (Lanyi, 1987). Susceptibility to antibiotics was tested on TSA plates by using antibiotic discs containing the following amounts of antibiotic: polymyxin B, $100 \mathrm{U}$; streptomycin, $50 \mu \mathrm{g}$; penicillin G, $20 \mathrm{U}$; chloramphenicol, $100 \mu \mathrm{g}$; ampicillin, $10 \mu \mathrm{g}$; cephalothin, $30 \mu \mathrm{g}$; gentamicin, $30 \mu \mathrm{g}$; novobiocin, $5 \mu \mathrm{g}$; tetracycline, $30 \mu \mathrm{g}$; kanamycin, $30 \mu \mathrm{g}$; lincomycin, $15 \mu \mathrm{g}$; oleandomycin, $15 \mu \mathrm{g}$; neomycin, $30 \mu \mathrm{g}$; and carbenicillin, $100 \mu \mathrm{g}$. Utilization of various substrates, activities of various enzymes and other physiological and biochemical properties were tested by using the API 20E, API 20NE, API $50 \mathrm{CH}$ and API ZYM systems (bioMérieux); the cells were suspended in AUX medium, according to the manufacturer's instructions, to inoculate the API $50 \mathrm{CH}$ system.

Cell biomass for DNA extraction and for isoprenoid quinone and polar lipid analyses was obtained from cultivation in trypticase soy broth (Difco) at $37^{\circ} \mathrm{C}$. Chromosomal DNA was isolated and purified according to the method described by Yoon et al. (1996), with the exception that RNase T1 was used in combination with RNase A to minimize contamination with RNA. The $16 \mathrm{~S}$ rRNA gene was amplified by a PCR using two universal primers as described previously (Yoon et al., 1998). Sequencing of the amplified 16S rRNA gene and phylogenetic analysis were performed as described by Yoon et al. (2003). Isoprenoid quinones were extracted according to the method of Komagata \& Suzuki (1987) and analysed using reversed-phase HPLC and a YMC ODS-A $(250 \times 4.6 \mathrm{~mm})$ column. For cellular fatty acid analysis, cell mass of strain $\mathrm{K} 110^{\mathrm{T}}$ and P. kullae DSM $13608^{\mathrm{T}}$ was harvested from TSA plates after incubation for 3 days at $37^{\circ} \mathrm{C}$. The fatty acids were extracted and the fatty acid methyl esters prepared according to the standard protocol of the MIDI/Hewlett Packard Microbial Identification System (Sasser, 1990). Polar lipids were extracted according to the procedures described by Minnikin et al. (1984) and then identified by two-dimensional TLC followed by spraying with appropriate detection reagents (Minnikin et al., 1984; Komagata \& Suzuki, 1987). The DNA G +C content was determined by the method of Tamaoka \& Komagata (1984), with the modification that the DNA was hydrolysed and the resulting nucleotides analysed by reversed-phase HPLC. DNA-DNA hybridization was performed fluorometrically by the method of Ezaki et al. (1989), using photobiotinlabelled DNA probes and microdilution wells. Hybridization was performed with five replications for each sample. The highest and lowest values obtained for each sample were excluded and the means for the remaining three values are quoted as the DNA-DNA relatedness values. Repetitive extragenic palindromic PCR (rep-PCR) genomic fingerprinting using REP, BOX and (GTG) $)_{5}$ PCR primers was performed as described by Rademaker et al. (1998). Computer-assisted analysis of the genomic fingerprints was performed by using GelCompar II software, version 1.5 (Applied Maths).

Morphological, cultural, physiological and biochemical characteristics of strain $\mathrm{K} 110^{\mathrm{T}}$ are given in the species description (see below) or are shown in Table 1. The almost-complete 16S rRNA gene sequence of strain $\mathrm{K} 110^{\mathrm{T}}$ determined in this study comprised $1486 \mathrm{nt}$, representing approximately $96 \%$ of the Escherichia coli $16 \mathrm{~S}$ rRNA gene sequence. Comparative 16S rRNA gene sequence analysis showed that strain $\mathrm{K} 110^{\mathrm{T}}$ was most closely related phylogenetically to the genus Pigmentiphaga (Fig. 1). In the neighbour-joining phylogenetic tree based on $16 \mathrm{~S}$ rRNA gene sequences, strain $\mathrm{K} 110^{\mathrm{T}}$ joined the type strain of $P$. kullae at a bootstrap resampling value of $100 \%$ (Fig. 1). Strain $\mathrm{K} 110^{\mathrm{T}}$ exhibited a $16 \mathrm{~S}$ rRNA gene sequence similarity value of $99.4 \%$ with respect to the type strain of $P$. kullae and showed less than $96.4 \%$ similarity with respect to other species included in the phylogenetic analysis.

The predominant isoprenoid quinone detected in strain $\mathrm{K} 110^{\mathrm{T}}$ was Q-8 (peak area ratio, approx. $94 \%$ ). Strain

Table 1. Differential phenotypic characteristics of strain $\mathrm{K} 110^{\top}$ and $P$. kullae DSM $13608^{\top}$

Data for P. kullae DSM $13608^{\mathrm{T}}$ were obtained from Blümel et al. (2001) and this study. Cells of both strains are Gram-negative, non-spore-forming rods. Both strains are positive for catalase, oxidase, hydrolysis of hypoxanthine, utilization of citrate, susceptibility to chloramphenicol, gentamicin, kanamycin, neomycin and polymyxin B, esterase (C4), esterase lipase (C8), leucine arylamidase, $\alpha$-chymotrypsin and naphthol-AS-BI-phosphohydrolase (weakly). Both are negative for the following: utilization of L-arabinose, ribose, D-xylose, adonitol, galactose, glucose, fructose, mannose, rhamnose, inositol, mannitol, sorbitol, $N$-acetylglucosamine, arbutin, salicin, cellobiose, maltose, melibiose, sucrose, trehalose and gluconate, nitrate reduction, hydrolysis of aesculin, casein, gelatin, starch, Tweens 20, 40, 60 and 80, tyrosine, urea and xanthine, susceptibility to ampicillin, cephalothin, lincomycin, novobiocin, oleandomycin, penicillin G and streptomycin and activity of alkaline phosphatase, lipase (C14), valine arylamidase, cystine arylamidase, trypsin, acid phosphatase, $\alpha$-galactosidase, $\beta$-galactosidase, $\beta$-glucuronidase, $\alpha$-glucosidase, $\beta$-glucosidase, $N$-acetyl- $\beta$-glucosaminidase, $\alpha$-mannosidase and $\alpha$-fucosidase.

\begin{tabular}{|lcc|}
\hline Characteristic & Strain K110 & P. kullae DSM $\mathbf{~ 1 3 6 0 8 ~}^{\mathbf{T}}$ \\
\hline Motility & - & + \\
Susceptibility to: & & - \\
Tetracycline & + & + \\
Carbenicillin & - & $\mathrm{PE}$ \\
Major polar lipid(s) & PG, PE, AL & $68.5 \pm 0.3(67.9) \dagger$ \\
DNA G + C content & 67.4 & \\
$($ mol\%) & & \\
\end{tabular}

*AL, Unidentified aminolipids; PE, phosphatidylethanolamine; PG, phosphatidylglycerol.

$\dagger$ Data from this study for strain DSM $13608^{\mathrm{T}}$ obtained using HPLC. 


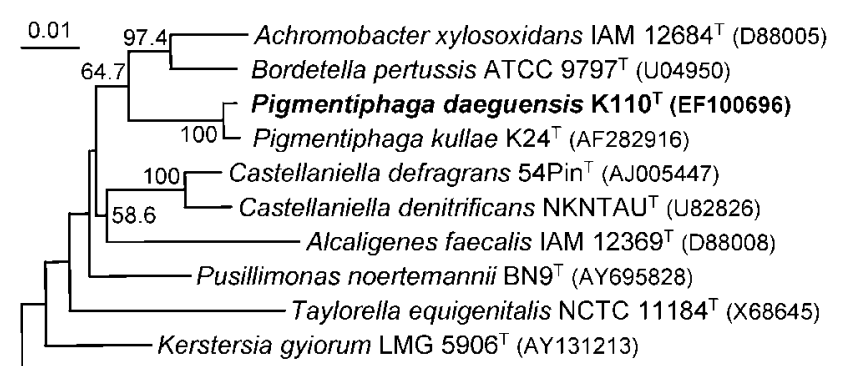

Burkholderia cepacia ATCC $25416^{\top}$ (M22518)

Fig. 1. Neighbour-joining phylogenetic tree, based on $16 \mathrm{~S}$ rRNA gene sequences, showing the positions of strain $\mathrm{K} 110^{\top}$ and some related taxa. Bootstrap percentages (based on 1000 replications) greater than $50 \%$ are shown at branching points. Burkholderia cepacia ATCC $25416^{\top}$ was used as an outgroup. Bar, 0.01 substitutions per nucleotide position.

$\mathrm{K} 110^{\mathrm{T}}$ had a cellular fatty acid profile that contained large amounts of straight-chain and hydroxy fatty acids; the major components ( $>10 \%$ of total fatty acids) were $\mathrm{C}_{16: 0}$, cyclo $\mathrm{C}_{17: 0}$ and cyclo $\mathrm{C}_{19: 0} \omega 8 c$ (see Supplementary Table S1, available in IJSEM Online). This fatty acid profile was similar to that of the type strain of $P$. kullae, although there were differences in the proportions of some fatty acids (Supplementary Table S1). The major polar lipids detected in strain $\mathrm{K}_{110^{\mathrm{T}}}$ were phosphatidylglycerol, phosphatidylethanolamine and two unidentified aminolipids; minor amounts of diphosphatidylglycerol and an unidentified phospholipid were also present. The DNA G $+\mathrm{C}$ content of strain $\mathrm{K} 110^{\mathrm{T}}$ was $67.4 \mathrm{~mol} \%$. These chemotaxonomic properties supported the result of the monothetic phylogenetic classification, namely that strain $\mathrm{K} 110^{\mathrm{T}}$ could be a member of the genus Pigmentiphaga. Strain $\mathrm{K}_{110^{\mathrm{T}}}$ is phenotypically similar to $P$. kullae, as shown in Table 1 . However, strain $\mathrm{K} 110^{\mathrm{T}}$ could be distinguished from P. kullae by notable differences in REP PCR genomic fingerprinting patterns (Supplementary Fig. S1 in IJSEM Online). DNADNA relatedness data were sufficient to categorize strain $\mathrm{K} 110^{\mathrm{T}}$ as representing a genomic species that is distinct from P. kullae (Wayne et al., 1987). The mean value for DNA-DNA relatedness between strain $\mathrm{K} 110^{\mathrm{T}}$ and the type strain of P. kullae was $34.6 \%$ when their DNAs were used individually as labelled DNA probes for cross-hybridization, indicating that they represent different genomic species. Therefore, on the basis of the phenotypic, phylogenetic and genetic data, strain $\mathrm{K} 110^{\mathrm{T}}$ should be classified within the genus Pigmentiphaga as a member of a novel species, for which the name Pigmentiphaga daeguensis sp. nov. is proposed.

\section{Description of Pigmentiphaga daeguensis sp. nov.}

Pigmentiphaga daeguensis (dae.gu.en'sis. N.L. fem. adj. daeguensis of Daegu, Korea, from where the type strain was isolated).
Cells are Gram-negative, non-spore-forming rods (0.3$0.6 \times 0.7-2.5 \mu \mathrm{m})$. Non-motile. Colonies on TSA are circular to slightly irregular, yellowish-white in colour and $1.0-2.0 \mathrm{~mm}$ in diameter after 3 days incubation at $37^{\circ} \mathrm{C}$. The optimal temperature for growth is $37^{\circ} \mathrm{C}$. Growth occurs at 15 and $46^{\circ} \mathrm{C}$, but not at 10 or $47^{\circ} \mathrm{C}$. The optimal pH for growth is 7.0-8.0; growth occurs at $\mathrm{pH} 5.0$ and 9.0, but not at $\mathrm{pH} 4.5$ or 9.5 . Growth occurs in the presence of $0-5 \%$ $(\mathrm{w} / \mathrm{v}) \mathrm{NaCl}$; optimal growth occurs in the presence of $0.5 \%$ $(\mathrm{w} / \mathrm{v}) \mathrm{NaCl}$. No anaerobic growth occurs on TSA or on TSA supplemented with nitrate. Arginine dihydrolase activity is weakly positive. Lysine decarboxylase, ornithine decarboxylase and tryptophan deaminase are absent. Adipate and malate are utilized, but glycerol, erythritol, D-arabinose, L-xylose, methyl $\beta$-D-xyloside, sorbose, dulcitol, methyl $\alpha$-D-mannoside, methyl $\alpha$-D-glucoside, amygdalin, aesculin, lactose, inulin, melezitose, raffinose, starch, glycogen, xylitol, gentiobiose, D-turanose, D-lyxose, D-tagatose, D- and L-fucose, D- and L-arabitol, 2-ketogluconate, 5-ketogluconate, caprate and phenylacetate are not. The predominant ubiquinone is Q-8. The major fatty acids ( $>10 \%$ of total fatty acids) are $\mathrm{C}_{16: 0}$, cyclo $\mathrm{C}_{17: 0}$ and cyclo $\mathrm{C}_{19: 0} \omega 8 \mathrm{c}$. The major polar lipids are phosphatidylglycerol, phosphatidylethanolamine and two unidentified aminolipids. The DNA $\mathrm{G}+\mathrm{C}$ content is $67.4 \mathrm{~mol} \%$ (determined by HPLC). Other phenotypic characteristics are given in Table 1.

The type strain, $\mathrm{K} 110^{\mathrm{T}}\left(=\mathrm{KCTC} 12838^{\mathrm{T}}=\mathrm{JCM} 14330^{\mathrm{T}}\right)$, was isolated from wastewater from a dye works at Daegu, Korea.

\section{Emended description of the genus Pigmentiphaga Blümel et al. 2001}

The description of the genus Pigmentiphaga is as given by Blümel et al. (2001), with the following amendments. Cells are motile or non-motile. Common major polar lipid is phosphatidylethanolamine. The DNA G $+\mathrm{C}$ content is 67.4-68.8 $\mathrm{mol} \%$.

\section{Acknowledgements}

This work was supported by the 21C Frontier Program of Microbial Genomics and Applications (grant MG05-0401-2-0) and the Support and Application Project of Biological Resources (grant M10508050004-06N0805-00410) from the Ministry of Science and Technology (MOST) of the Republic of Korea.

\section{References}

Blümel, S., Mark, B., Busse, H.-J., Kämpfer, P. \& Stolz, A. (2001). Pigmentiphaga kullae gen. nov., sp. nov., a novel member of the family Alcaligenaceae with the ability to decolorize azo dyes aerobically. Int J Syst Evol Microbiol 51, 1867-1871.

Cowan, S. T. \& Steel, K. J. (1965). Manual for the Identification of Medical Bacteria. London: Cambridge University Press.

Ezaki, T., Hashimoto, Y. \& Yabuuchi, E. (1989). Fluorometric deoxyribonucleic acid-deoxyribonucleic acid hybridization in microdilution wells as an alternative to membrane filter hybridization in 
which radioisotopes are used to determine genetic relatedness among bacterial strains. Int J Syst Bacteriol 39, 224-229.

Komagata, K. \& Suzuki, K. (1987). Lipid and cell wall analysis in bacterial systematics. Methods Microbiol 19, 161-203.

Lanyi, B. (1987). Classical and rapid identification methods for medically important bacteria. Methods Microbiol 19, 1-67.

Minnikin, D. E., O’Donnell, A. G., Goodfellow, M., Alderson, G., Athalye, M., Schaal, A. \& Parlett, J. H. (1984). An integrated procedure for the extraction of bacterial isoprenoid quinones and polar lipids. J Microbiol Methods 2, 233-241.

Rademaker, J. L. W., Louws, F. J. \& de Bruijn, F. J. (1998). Characterization of the diversity of ecologically important microbes by rep-PCR genomic fingerprinting. In Molecular Microbial Ecology Manual, supplement 3, chapter 3.4.3, pp. 1-26. Edited by A. D. L. Akkermans, J. D. van Elsas \& F. J. de Bruijn. Dordrecht: Kluwer.

Sasser, M. (1990). Identification of bacteria by gas chromatography of cellular fatty acids, Technical Note 101. Newark, DE: MIDI Inc.
Tamaoka, J. \& Komagata, K. (1984). Determination of DNA base composition by reversed-phase high-performance liquid chromatography. FEMS Microbiol Lett 25, 125-128.

Wayne, L. G., Brenner, D. J., Colwell, R. R., Grimont, P. A. D., Kandler, O., Krichevsky, M., Moore, L. H., Moore, W. E. C., Murray, R. G. E. \& other others (1987). International Committee on Systematic Bacteriology. Report of the ad hoc committee on reconciliation of approaches to bacterial systematics. Int J Syst Bacteriol 37, 463-464.

Yoon, J.-H., Kim, H., Kim, S.-B., Kim, H.-J., Kim, W. Y., Lee, S. T., Goodfellow, M. \& Park, Y.-H. (1996). Identification of Saccharomonospora strains by the use of genomic DNA fragments and rRNA gene probes. Int J Syst Bacteriol 46, 502-505.

Yoon, J.-H., Lee, S. T. \& Park, Y.-H. (1998). Inter- and intraspecific phylogenetic analysis of the genus Nocardioides and related taxa based on 16S rRNA gene sequences. Int J Syst Bacteriol 48, 187-194. Yoon, J.-H., Kang, K. H. \& Park, Y.-H. (2003). Psychrobacter jeotgali sp. nov., isolated from jeotgal, a traditional Korean fermented seafood. Int J Syst Evol Microbiol 53, 449-454. 